\title{
Effects of growth hormone treatment on growth plate, bone, and mineral metabolism of young rats with uremia induced by adenine
}

Débora Claramunt, Helena Gil-Peña, Rocío Fuente, Enrique García-López, Olaya Hernández Frías, Flor A. Ordoñez, Julián Rodríguez-Suárez and Fernando Santos

Correction to: Pediatric Research advance online publication, April 26, 2017; doi:10.1038/pr.2017.95

The Acknowlegments section of the published version of this article is incomplete. It should have included the following statement:

This work was supported partially by University of Oviedo, FEDER Funds, ISC III FIS PI12/00987, PI15/02122, Plan Estatal I +D+I 2013-2016, Fundación Bancaria Cajastur, and Fundación Nutrición y Crecimiento.

The authors regret the omission. 